\title{
Literature Review: Faktor-faktor yang Berhubungan dengan Kejadian Kurang Energi Kronis (KEK) pada Remaja Putri
}

\section{Literature Review: Factors That Related with Chronic Energy Deficiency in Adolescent Girls}

\author{
Alvi 'Izza Ardi*
}

\begin{abstract}
ABSTRAK
Latar Belakang: Remaja putri sering mengalami masalah gizi kurang energi kronis. Kurang energi kronis merupakan kondisi yang terjadi karena asupan energi dan protein yang kurang dalam jangka waktu lama. Remaja putri usia 15-19 tahun memiliki proporsi yang paling tinggi diantara wanita usia subur yang mengalami kurang energi kronis pada tahun 2018. Usia remaja mengalami perubahan yang berlangsung cepat dalam hal pertumbuhan fisik, kognitif, dan psikososial. Kurang energi kronis dapat berdampak buruk bagi remaja putri hingga fase kehidupan selanjutnya.

Tujuan: Tujuan dari studi literatur ini adalah untuk mengetahui faktor-faktor yang berhubungan dengan kejadian kurang energi kronis pada remaja putri.

Metode: Jenis penelitian ini adalah studi literatur yang berasal dari Google Scholar. Referensi jurnal yang digunakan sebagai referensi berjumlah 6 jurnal yang relevan dengan topik studi literatur ini.

Hasil: Variabel yang memiliki hubungan dengan kurang energi kronis pada remaja putri adalah pola makan (frekuensi makan dan jenis ragam makanan), asupan zat gizi (energi, protein, lemak, zat besi), body image, dan indeks massa tubuh menurut umur. Sebagian besar remaja putri yang memiliki pola makan yang tidak sesuai pedoman gizi seimbang, kurang asupan zat besi, dan body image negatif mengalami kurang energi kronis. Remaja putri yang sebagian besar mempunyai asupan energi, protein, dan lemak yang baik tidak mengalami kurang energi kronis.

Kesimpulan: Terdapat hubungan antara pola makan (frekuensi makan dan jenis ragam makanan), asupan zat gizi (energi, protein, lemak, zat besi), body image, dan indeks massa tubuh menurut umur dengan kurang energi kronis pada remaja putri. Indeks massa tubuh menurut umur memiliki hubungan yang sangat kuat dengan kurang energi kronis.
\end{abstract}

Kata kunci: kurang energi kronis, remaja putri

\begin{abstract}
Background: Adolescent girls often experience chronic energy deficiency problems. Chronic energy deficiency is a condition that occurs due to insufficient energy and protein intake over a long period of time. Adolescent girls aged 15-19 years have the highest proportion among women of childbearing age who experience chronic energy deficiency in 2018. Adolescents experience rapid changes in terms of physical, cognitive, and psychosocial growth. Chronic energy deficiency can have a negative impact on adolescent girls until the next phase of life.

Objectives: The purpose of this literature review was to determine the factors associated with the incidence of chronic energy deficiency in adolescent girls.

Methods: This type of research is a literature review that comes from GoogleScholar. There are 6 journal references that are used as references that are relevant to the topic of this literature review.

Results: Variables that have a relationship with chronic energy deficiency in adolescent girls are diet (frequency of eating and variety of food), nutrient intake (energy, protein, fat, iron), body image, and body mass index for age. Most of adolescent girls who have a diet that is not in accordance with guidelines of balanced nutrition, lack of iron intake, and negative body image experience chronic energy deficiency. Adolescent girls who mostly have a good intake of energy, protein, and fat do not experience chronic energy deficiency.
\end{abstract}


Conclusion: There is a relationship between diet (frequency of eating and types of food variety), nutrient intake (energy, protein, fat, iron), body image, and body mass index for age with chronic energy deficiency. Body mass index for age has a very strong relationship with chronic energy deficiency.

Keywords: chronic energy deficiency, adolescent girls

\author{
*Koresponden: \\ alviizza28@gmail.com \\ Alvi 'Izza Ardi \\ ${ }^{1}$ Departemen Gizi, Fakultas Kesehatan Masyarakat, Universitas Airlangga, Kampus C Mulyorejo, 60115, \\ Surabaya, Jawa Timur, Indonesia
}

\title{
PENDAHULUAN
}

Salah satu masalah gizi yang mengancam remaja Indonesia adalah kurang energi kronis (KEK) (Kementerian Kesehatan RI, 2018). Remaja yang mengalami KEK dapat disebabkan oleh kurangnya asupan zat gizi karena alasan ekonomi ataupun psikososial seperti penampilan (Kementerian Kesehatan RI, 2018). Asupan energi yang kurang dapat menyebabkan simpanan energi dalam tubuh rendah dan penurunan berat badan (Arista et al, 2017). KEK dapat diketahui dengan ukuran lingkar lengan atas (LILA) wanita usia subur kurang dari 23,5 $\mathrm{cm}$ (Harahap, 2002).

Wanita usia subur (WUS) merupakan wanita yang tergolong usia 15-49 tahun dengan organ reproduksi sudah matang dan berfungsi degan baik (Depkes, 2004). Data Riset Kesehatan Dasar tahun 2018 menunjukkan sebanyak 14,5\% WUS KEK tidak hamil dan 17,3\% WUS KEK hamil. Berdasarkan kelompok usia, proporsi KEK pada WUS yang tertinggi berada pada usia 15-19 tahun. Pada kelompok usia tersebut, sebanyak 36,3\% WUS KEK tidak hamil dan 33,5\% WUS KEK hamil (Kemenkes, 2018).

Menurut WHO, usia 15-19 tahun tergolong ke dalam usia remaja (World Health Organization, 2018). Remaja mengalami penambahan massa otot, penambahan jaringan lemak tubuh, dan perubahan hormon yang dapat mempengaruhi kebutuhan gizinya (Hardinsyah dan Supariasa, 2016). Kebutuhan gizi yang dapat terpenuhi dari asupan makanan yang cukup berguna untuk menjalankan kegiatan fisik remaja yang sangat meningkat (Noviyanti dan Marfuah, 2017). Namun, kebutuhan gizi yang tidak terpenuhi dapat menyebabkan kurangnya energi yang dihasilkan tubuh sehingga terjadi kekurangan zat gizi (Ertiana dan Wahyuningsih, 2019).

KEK memiliki dampak buruk bagi masa remaja maupun fase kehidupan selanjutnya. Dampak buruk KEK pada masa remaja adalah anemia, perkembangan organ yang kurang optimal, pertumbuhan fisik yang kurang, dan mempengaruhi produktivitas kerjanya (Yulianasari et al., 2019). Remaja yang mengalami KEK hingga fase ibu hamil dapat berpengaruh buruk terhadap janin, seperti keguguran, bayi lahir mati, kematian neonatal, cacat bawaan, anemia pada bayi, dan bayi berat lahir rendah, sedangkan saat persalinan dapat mengakibatkan persalinan sulit dan lama, persalinan sebelum waktunya, dan pendarahan (Maharani et al., 2018).

Berdasarkan latar belakang tersebut, peneliti tertarik untuk mengetahui faktor-faktor yang berhubungan dengan kejadian kurang energi kronis pada remaja putri. Literatur yang digunakan sebagai bahan review berupa jurnal nasional terakreditasi dan prosiding seminar nasional.

\section{METODE}

Metode yang digunakan pada penulisan artikel ini adalah studi literatur. Pencarian literatur dilakukan secara online dengan menggunakan database Google Scholar. Pencarian literatur menggunakan kata kunci kurang energi kronis (KEK) dan remaja putri. Kriteria inklusi yang digunakan untuk menyeleksi literatur adalah jurnal yang berkaitan dengan hubungan suatu variabel dengan KEK, subjek remaja putri, dan jurnal dipublikasikan 5 tahun terakhir. Kriteria eksklusi dari studi literatur ini adalah subjek remaja putri yang tidak termasuk usia 15-19 tahun atau tergolong siswi SMA.

Hasil pencarian yang dilakukan peneliti dengan kata kunci, beberapa membahas tentang KEK pada wanita usia subur yang usianya di atas remaja putri, termasuk ibu hamil. Peneliti menemukan 60 jurnal yang membahas KEK pada remaja putri dengan rentang waktu 2016-2021. Jurnal yang telah ditemukan tersebut kemudian diseleksi untuk mencari jurnal yang membahas hubungan suatu variabel dengan KEK atau faktor yang berhubungan dengan KEK. Hasil seleksi menghasilkan 6 jurnal yang sesuai dengan kriteria inklusi dan eksklusi yang telah ditentukan peneliti. Jurnal lain dieliminasi karena banyak membahas mengenai gambaran KEK pada remaja atau gambaran suatu variabel pada remaja KEK dan pengaruh suatu variabel dengan KEK. 


\section{HASIL DAN PEMBAHASAN}

\section{Hubungan Pola Makan dengan Kejadian KEK}

Penelitian yang dilakukan oleh (Wardhani et al., 2020) menunjukkan bahwa frekuensi makan berhubungan dengan KEK pada remaja putri dengan nilai signifikansi sebesar 0,000. Sebanyak 76,1\% dari 88 remaja putri dengan frekuensi makan tidak sesuai PGS (Pedoman Gizi Seimbang) mengalami KEK. Pada penelitian tersebut, nilai odds ratio (OR) sebesar 4,669. Makna dari OR itu adalah remaja putri dengan frekuensi makan tidak sesuai PGS memiliki kecenderungan 4,669 kali mengalami KEK (Wardhani et al., 2020).

Pola makan dapat menggambarkan frekuensi, macam, dan bahan makanan yang dikonsumsi sehari-hari (Suryani et al., 2015). Makanan yang dikonsumsi sesuai jumlah kebutuhan dapat menghasilkan zat gizi yang cukup untuk aktivitas fisik (Rahayu dan Fitriana, 2018). Kebiasaan makan yang ideal adalah makan tiga kali sehari dengan rentang waktu yang hampir sama dalam sehari ditambah makan selingan dua kali dengan porsi kecil (Muhayati dan Ratnawati, 2019). Namun, seringkali remaja melewatkan makan karena kegiatan sehariharinya yang padat (Ruaida dan Marsaoly, 2017). Hal tersebut dapat mempengaruhi pertumbuhan dan perkembangannya (Rahayu dan Fitriana, 2018).

Menurut (Wardhani et al., 2020), ada hubungan antara jenis ragam makanan dengan KEK pada remaja putri dengan nilai signifikansi sebesar 0,000. Sebagian besar remaja putri yang mengonsumsi makanan kurang beragam mengalami KEK. Nilai OR sebesar 6,068 berarti remaja putri yang konsumsi makanan kurang beragam memiliki peluang 6,068 kali mengalami KEK (Wardhani et al., 2020).

Penelitian yang dilakukan oleh (Ertiana dan Wahyuningsih, 2019) menyatakan asupan makan berhubungan dengan KEK pada remaja putri dengan nilai signifikansi sebesar 0,000. Nilai keeratan hubungan sebesar 0,395 berarti asupan makan dan KEK memiliki hubungan yang cukup. Asupan makan dalam penelitian ini dibedakan menjadi bervariasi dan tidak bervariasi. Sebanyak 71,5\% remaja putri tidak KEK memiliki asupan makan yang bervariasi (Ertiana dan Wahyuningsih, 2019).

Pada masa remaja, makanan sudah tidak ditentukan lagi oleh orang tua, tetapi diri mereka sendiri bebas memilih makanan yang dikonsumsi (Noviyanti dan Marfuah, 2017). Remaja menunjukkan kebiasaan makan mengkonsumsi makanan jajanan seperti gorengan, minum-minuman berwarna, soft drink, dan konsumsi fast food yang banyak mengandung lemak, gula, dan zat aditif (Hafiza et al., 2020). Konsumsi makanan yang beragam berguna untuk memenuhi zat gizi yang diperlukan tubuh karena tidak ada satupun jenis makanan yang mengandung zat gizi lengkap yang diperlukan tubuh, kecuali air susu ibu (Kemenkes, 2014). Remaja perlu mengkonsumsi makanan yang bervariasi dan cukup mengandung energi dan protein sekurang-kurangnya sehari sekali (Syahfitri, 2020).

Pada studi literatur ini, pola makan yang dibedakan menjadi frekuensi makan dan jenis ragam makanan memiliki hubungan dengan KEK pada remaja putri. Keanekaragaman pangan tidak hanya dilihat dari aneka ragam jenis pangannya, tetapi jumlah yang dikonsumsi juga perlu diperhatikan (Kemenkes, 2014). Jika pola makan memenuhi kebutuhan gizi tubuh dari segi kuantitas maupun kualitas, maka tubuh akan memiliki keadaan gizi yang baik (Miko dan Dina, 2016). Pola makan yang buruk pada remaja dapat meningkatkan risiko terjadinya KEK pada remaja (Ertiana dan Wahyuningsih, 2019).

\section{Hubungan Asupan Zat Gizi dengan Kejadian KEK}

Penelitian yang dilakukan oleh (Telisadan Eliza, 2020) menunjukkan bahwa ada hubungan antara asupan energi, protein, lemak dengan KEK pada remaja putri, sedangkan asupan karbohidrat tidak berhubungan dengan KEK pada remaja putri. Nilai OR asupan energi menunjukkan hasil 4,9 berarti remaja putri yang memiliki asupan energi kurang berpeluang 4,9 kali mengalami KEK. Asupan protein mempunyai nilai OR sebesar 4,7 yang bermakna remaja putri dengan asupan protein kurang memiliki peluang 4,7 kali mengalami KEK. Hasil nilai OR asupan lemak sebesar 3,3 berarti remaja putri yang memiliki asupan lemak kurang mempunyai kecenderungan 3,3 kali mengalami KEK (Telisa dan Eliza, 2020).

Penelitian tersebut sejalan dengan penelitian yang dilakukan oleh (Zaki et al., 2017) bahwa asupan energi, protein, dan lemak berhubungan dengan KEK pada remaja putri, sedangkan asupan karbohidrat tidak berhubungan dengan KEK pada remaja putri. Nilai keeratan hubungan asupan energi, protein, dan lemak berturut-turut 0,28; 0,36; dan 0,26. Nilai tersebut bermakna asupan energi, protein, dan lemak dan KEK pada remaja putri memiliki keeratan hubungan yang cukup. Keeratan hubungan yang positif dapat diinterpretasikan bahwa semakin besar asupan energi, protein, dan lemak dapat meningkatkan nilai LiLA (Zaki et al., 2017).

Penelitian yang dilakukan oleh (Ruaida dan Marsaoly, 2017) menunjukkan hasil yang berbeda dengan penelitian sebelumnya. Hasil penelitian menyatakan bahwa tingkat konsumsi energi dan protein tidak berhubungan dengan KEK pada remaja putri (Ruaida dan Marsaoly, 2017). Hasil tersebut sejalan dengan penelitian yang dilakukan oleh Arista et al., (2017) bahwa tidak ada hubungan antara tingkat konsumsi energi dan protein dengan KEK pada remaja putri. 
Lingkar lengan atas dapat menggambarkan ketersediaan zat gizi di otot dan lemak bawah kulit. Energi dapat disimpan sebagai cadangan dalam bentuk jaringan adiposa yang berada di lemak bawah kulit. Oleh karena itu, lingkar lengan atas dapat digunakan sebagai indikator untuk melihat riwayat asupan gizi pada masa lampau (Telisa dan Eliza, 2020).

Asupan zat gizi makro yang tidak memenuhi kebutuhan dapat disebabkan oleh pola makan yang tidak teratur seperti melewatkan waktu makan utama dan mengonsumsi makanan yang mengandung rendah protein (Sitoayu et al., 2017). Konsumsi makanan olahan yang meningkat dengan nilai gizi yang kurang dapat menyebabkan remaja rentan kekurangan zat gizi (Telisa dan Eliza, 2020). Pada masa remaja, sulit mengubah kebiasaan makan yang dikonsumsinya, tetapi remaja mau mengubahnya jika ada keuntungan didalamnya (Ertiana dan Wahyuningsih, 2019).

Asupan energi yang tidak mencukupi kebutuhan menyebabkan tubuh akan mengubah cadangan lemak menjadi energi. Apabila cadangan lemak secara terus menerus digunakan oleh tubuh sebagai energi hingga habis, maka simpanan protein di hati dan otot akan diubah menjadi energi oleh tubuh. Apabila simpanan protein terus menerus digunakan, maka akan menyebabkan masa otot mengalami deplesi sehingga terjadi kurang energi kronis (KEK) (Putri et al., 2019).

Menurut (Telisa dan Eliza, 2020), terdapat hubungan antara asupan zat besi dengan kejadian KEK pada remaja putri dengan nilai signifikansi sebesar 0,000. Nilai OR menunjukkan nilai sebesar 11,0. Nilai tersebut bermakna remaja putri yang memiliki asupan zat besi kurang berisiko 11 kali lebih besar mengalami KEK (Telisa dan Eliza, 2020).

Pada remaja putri, kebutuhan zat besi meningkat karena beberapa zat besi yang hilang selama menstruasi (Sari et al., 2019). Zat besi berperan penting dalam membantu hemoglobin mengangkut oksigen dan membantu berbagai enzim mengikat oksigen untuk proses metabolisme tubuh (Agustina dan Fridayanti, 2017). Kebutuhan zat besi yang tidak cukup terpenuhi dari diet makanan, maka dapat ditambah suplemen zat besi sesuai dengan konsumsi yang dianjurkan (Listiana, 2016). Namun, penelitian yang dilakukan oleh (Agustina dan Fridayanti, 2017) menyatakan kurangnya asupan zat besi pada remaja putri disebabkan oleh remaja putri tidak pernah mengonsumsi suplemen zat besi.

Penyebab lain kurangnya asupan zat besi pada remaja putri adalah seringnya mengonsumsi sumber zat besi non-heme dan zat penghambat absorpsi zat besi (Sholicha dan Muniroh, 2019). Zat besi non-heme yang berasal dari sumber nabati memiliki bioavailabilitas zat besi yang rendah (Arima et al., 2019). Beberapa remaja putri menghindari konsumsi hati sapi atau hati ayam karena tidak suka dengan rasanya dan baunya amis dan menghindari konsumsi daging sapi atau keju dengan alasan mengandung lemak yang tinggi (Rahayu dan Dieny, 2012). Apabila asupan zat besi yang kurang disertai dengan seringnya konsumsi zat penghambat absorpsi zat besi, maka kadar zat besi di dalam tubuh dapat menjadi rendah (Sholicha dan Muniroh, 2019).

Asupan zat gizi yang berhubungan dengan KEK pada studi literatur ini adalah energi, protein, lemak, dan zat besi. Diantara asupan zat gizi makro, asupan energi remaja putri yang kurang memiliki risiko yang lebih besar dari pada protein dan lemak sebesar 4,9 kali mengalami KEK. Asupan zat besi yang kurang pada remaja putri berisiko 11 kali lebih besar mengalami KEK.

\section{Hubungan Body Image dengan Kejadian KEK}

Penelitian yang dilakukan oleh (Wardhani et al., 2020) menyatakan bahwa terdapat hubungan antara body image dengan kejadian KEK pada remaja putri. Body image dalam penelitian ini dibagi menjadi 5 variabel yang terdiri dari appearance evaluation, appearance orientation, body area satisfaction, overweight preoccupation, dan self-classified weight. Appearance evaluation merupakan penilaian penampilan secara keseluruhan oleh diri sendiri dengan menilai tubuh yang dimiliki menarik atau kurang menarik dan kepuasan penampilan dirinya. Sebagian besar remaja putri menilai penampilannya kurang menarik atau kurang sesuai dengan yang diinginkannya. Hasil penelitian menunjukkan nilai signifikansi sebesar 0,000 yang berarti terdapat hubungan antara appearance evaluation dengan KEK pada remaja putri. Nilai OR sebesar 3,226 yang berarti remaja putri dengan body image negatif memiliki kecenderungan 3,226 kali mengalami KEK (Wardhani et al., 2020).

Appearance orientation, yaitu orientasi atau kepedulian seseorang terhadap penampilan dirinya dan usaha yang dilakukan untuk memperbaiki penampilannya. Sebagian besar remaja putri memiliki pandangan yang positif terhadap penampilan dirinya. Hasil penelitian menunjukkan nilai signifikansi sebesar 0,006 bermakna ada hubungan antara appearance orientation dengan KEK pada remaja putri. Nilai OR diperoleh sebesar 2,380 yang artinya remaja putri dengan body image negatif berisiko 2,380 kali mengalami KEK (Wardhani et al., 2020).

Body area satisfaction adalah penilaian kepuasan individu terhadap bagian tubuhnya secara spesifik, seperti rambut, wajah, tubuh bagian tengah (pinggang, perut), tubuh bagian bawah (pinggul, pantat, paha, kaki), tampilan otot, tinggi badan, dan berat badan. Hasil penelitian menyatakan remaja putri merasa tidak puas dengan beberapa bagian tubuhnya terutama tubuh bagian tengah. Nilai signifikansi menunjukkan nilai 0,015 yang berarti body area satisfaction berhubungan dengan KEK pada remaja putri. Remaja putri dengan body image negatif 
memiliki kecenderungan 2,148 kali mengalami KEK yang ditunjukkan dari nilai OR sebesar 2,148 (Wardhani et al., 2020).

Overweight preoccupation merupakan penilaian terkait kecemasan dan kewaspadaan individu terhadap penambahan berat badan. Hasil penelitian menyatakan sebagian besar remaja putri tidak terlalu cemas apabila berat badannya bertambah. Nilai signifikansi sebesar 0,003 berarti ada hubungan antara overweight preoccupation dengan KEK pada remaja putri. Nilai OR sebesar 2,596 yang artinya remaja putri dengan body image negatif berisiko 2,596 kali lebih tinggi mengalami KEK (Wardhani et al., 2020).

Self-classified weight adalah persepsi seseorang dalam menilai berat badannya dan mengklasifikasikan tubuhnya sendiri. Hasil penelitian menunjukkan sebagian besar remaja putri menilai ukuran tubuhnya normal. Nilai signifikansi yang diperoleh sebesar 0,000 berarti self-classified weight berhubungan dengan KEK pada remaja putri. Remaja putri dengan body image negatif memiliki kecenderungan 3,373 kali mengalami KEK yang ditunjukkan dengan nilai OR sebesar 3,373 (Wardhani et al., 2020).

Remaja putri seringkali memiliki pandangan yang salah mengenai tubuhnya (Notoatmodjo, 2010). Remaja putri menginginkan bentuk tubuh yang ideal (Yusinta et al., 2019). Ketidakpuasan remaja putri terhadap body image yang dimilikinya dapat dipengaruhi oleh media dan tren saat ini (Yusintha dan Adriyanto, 2018). Akibat dari ketidakpuasan remaja putri terhadap bentuk tubuhnya bermacam-macam, salah satunya adalah kepercayaan diri yang rendah (Ifdil et al., 2017). Hal tersebut membuat remaja putri melakukan berbagai upaya untuk mencapai berat badan yang diinginkan (Marlina dan Ernalia, 2020).

Beberapa usaha yang dilakukan remaja putri untuk memperbaiki penampilannya adalah diet, olahraga, perawatan tubuh, dan konsumsi obat pelangsing agar berat badan berkurang (Wardhani et al., 2020). Banyak remaja yang menginginkan berat badan turun dengan cepat melalui diet ketat, tetapi tidak disesuaikan dengan gizi yang dibutuhkan (Yusinta et al., 2019). Diet ketat dapat menyebabkan perilaku seperti melewatkan waktu makan, mengganti makan utama dengan makan selingan, dan memuntahkan makanan yang dikonsumsi (Marlina dan Ernalia, 2020). Perilaku tersebut dapat mempengaruhi pemenuhan asupan gizi harian remaja putri (Margiyanti, 2021). Asupan gizi yang kurang dapat menyebabkan terjadinya KEK (Zaki et al., 2017).

\section{Hubungan Indeks Massa Tubuh Menurut Umur dengan Kejadian KEK}

Penelitian yang dilakukan oleh (Arista et al., 2017) menyatakan ada hubungan antara indeks massa tubuh menurut umur (IMT/U) dengan kejadian KEK pada remaja putri dengan nilai signifikansi sebesar 0,000. Nilai koefisien korelasi menunjukkan nilai 0,923 yang berarti IMT/U dengan KEK memiliki hubungan yang sangat kuat. Apabila remaja putri memiliki IMT/U kurang (kurus dan sangat kurus) berisiko mengalami KEK (Arista et al., 2017).

Indeks massa tubuh menurut umur merupakan penilaian status gizi terhadap anak berusia lebih dari 5 tahun sampai dengan 18 tahun (Kemenkes, 2020). Hasil penelitian yang dilakukan oleh (Arista et al., 2017) menunjukkan sebagian besar remaja putri memiliki status gizi yang normal. Status gizi yang nornal dapat mencerminkan kualitas dan kuantitas makanan yang dikonsumsi telah memenuhi kebutuhan tubuh (Pujiati et al., 2015).

Pada umumnya, status gizi remaja dipengaruhi oleh kebiasaan makan (Rahayu dan Fitriana, 2018). Kebiasaan makan remaja yang tidak baik, seperti melewatkan sarapan, konsumsi sayur dan buah yang rendah, konsumsi fast food yang tinggi, konsumsi jajanan yang tidak sehat, dan konsumsi makanan olahan tinggi gula (Nuryani, 2019). Banyak remaja yang tidak mementingkan asupan energi yang masuk dan keluar (Hafiza et al., 2020). Apabila energi yang keluar lebih besar dari pada energi yang masuk, maka dapat mengakibatkan kekurangan gizi (Almatsier, 2009). Remaja yang mengalami kekurangan gizi dalam waktu lama dapat menyebabkan terjadinya KEK (Paramata dan Sandalayuk, 2019).

\section{Kelebihan dan Kekurangan Studi Literatur}

Studi literatur ini memiliki kelebihan, yaitu terdapat beberapa faktor yang dibahas memiliki hubungan dengan kurang energi kronis pada remaja putri. Kekurangan dari studi literatur ini adalah jurnal yang digunakan sebagai referensi sedikit, tetapi variabel yang dibahas cukup banyak.

\section{KESIMPULAN}

Dalam studi literatur ini, faktor-faktor yang berhubungan dengan kejadian KEK pada remaja putri, yaitu pola makan, asupan zat gizi, body image, dan indeks massa tubuh menurut umur (IMT/U). Pola makan terdiri dari frekuensi makan dan jenis ragam makanan. Asupan zat gizi yang memiliki hubungan dengan KEK adalah energi, protein, lemak, dan zat besi. Body image terdiri dari 5 variabel, yaitu appearance evaluation, appearance orientation, body area satisfaction, overweight preoccupation, dan self-classified weight. Kelima variabel tersebut berhubungan dengan kejadian KEK. IMT/U memiliki hubungan yang sangat kuat dengan kejadian KEK yang ditunjukkan dengan nilai koefisien korelasi sebesar 0,923. 


\section{ACKNOWLEDGEMENT}

Penulis mengucapkan terima kasih kepada semua pihak yang terlibat dalam penyusunan studi literatur ini. Penulis berharap studi literatur ini dapat menjadi bahan bacaan untuk menambah wawasan pembaca.

\section{REFERENSI}

Agustina, E. E. dan Fridayanti, W. (2017) 'Determinan Risiko Kejadian Anemia pada Remaja Putri Berdasarkan Jenjang Pendidikan di Kabupaten Kebumen’, Bidan Prada: Jurnal Ilmiah Kebidanan, 8(1), pp. 57-70.

Almatsier, S. (2009) Prinsip Dasar Ilmu Gizi. Jakarta: Gramedia Pustaka Utama.

Arima, L. A. T., Murbawani, E. A. dan Wijayanti, H. S. (2019) 'Hubungan Asupan Zat Besi Heme, Zat Besi Non-Heme dan Fase Menstruasi dengan Serum Feritin Remaja Putri', Journal of Nutrition College, 8(2), pp. 87-94.

Arista, A. D., Widajanti, L. dan Aruben, R. (2017) 'Hubungan Pengetahuan, Sikap, Tingkat Konsumsi Energi, Protein, dan Indeks Massa Tubuh/Umur dengan Kekurangan Energi Kronik pada Remaja Putri', Jurnal Kesehatan Masyarakat (e-Journal), 5(4), pp. 585-591.

Depkes (2004) Penyelenggaraan Perbaikan Gizi Masyarakat. Jakarta: Departemen Kesehatan RI.

Ertiana, D. dan Wahyuningsih, P. S. (2019) 'Asupan Makan dengan Kejadian KEK pada Remaja Putri di SMAN 2 Pare Kabupaten Kediri', Jurnal Gizi KH, 1(2), pp.102-109.

Hafiza, D., Utami, A. dan Niriyah, S. (2020) 'Hubungan Kebiasaan Makan dengan Status Gizi pada Remaja SMP YLPI Pekanbaru', Jurnal Medika Hutama, 2(1), pp. 332-342.

Harahap, H. (2002) Faktor-faktor yang Mempengaruhi Risiko Kurang Energi Kronik (KEK) pada Wanita Usia Subur. [Online] Tersedia di: http://repository.litbang.kemkes.go.id/160/ (Diakses pada tanggal 20 Juni 2021).

Hardinsyah dan Supariasa, I. D. N. (2016) Ilmu Gizi Teori \& Aplikasi. Jakarta: Buku Kedokteran EGC.

Ifdil, I., Denich, A. U. dan Ilyas, A. (2017) 'Hubungan Body Image dengan Kepercayaan Diri Remaja Putri' Jurnal Kajian Bimbingan dan Konseling, 2(3), pp. 107-113.

Kemenkes (2014) Peraturan Menteri Kesehatan Republik Indonesia Nomor 41 Tahun 2014. [Online] Tersedia di: https://peraturan.bpk.go.id/Home/Details/119080/permenkes-no-41-tahun-2014 (Diakses pada tanggal 1 Juni 2021).

Kemenkes (2018) Hasil Utama RISKESDAS 2018. [Online] Tersedia di: https://kesmas.kemkes.go.id/assets/upload/dir_519d41d8cd98f00/files/Hasil-riskesdas-2018_1274.pdf (Diakses tanggal 1 Juni 2021).

Kemenkes (2020) Peraturan Menteri Kesehatan Republik Indonesia Nomor 2 Tahun 2020. [Online] Tersedia di https://peraturan.bpk.go.id/Home/Details/152505/permenkes-no-2-tahun-2020 (Diakses pada tanggal 1 Juni 2021).

Kementerian Kesehatan RI (2018) Kenali Masalah Gizi yang Ancam Remaja Indonesia. [Online] Tersedia di: https://www.kemkes.go.id/article/view/18051600005/kenali-masalah-gizi-yang-ancam-remajaindonesia.html (Diakses pada tanggal 20 Juni 2021).

Listiana, A. (2016) 'Analisis Faktor-faktor yang Berhubungan dengan Kejadian Anemia Gizi Besi pada Remaja Putri di SMKN 1 Terbanggi Besar Lampung Tengah', Jurnal Kesehatan, 8(3), pp. 455-469.

Maharani, N. A., Indriasari, R. dan Yustini (2018) Gambaran Asupan Gizi dan Anemia Remaja Putri KEK di SMA Al-Bahrah [Online] Jeneponto. Tersedia di: http://digilib.unhas.ac.id/uploaded_files/temporary/DigitalCollection/YjQ4ODEyYjM2MzBjM2M1Yjk2 ZTliMzg3MzlkZWU5NDljZDI4N2FmNg==.pdf (Diakses pada tanggal 20 Juni 2021).

Margiyanti, N. J. (2021) 'Analisis Tingkat Pengetahuan, Body Image dan Pola Makan terhadap Status Gizi Remaja Putri', Jurnal Akademika Baiturrahim Jambi (JABJ), 10(1), pp. 231-237.

Marlina, Y. dan Ernalia, Y. (2020) 'Hubungan Persepsi Body Image dengan Status Gizi Remaja Pada Siswa SMP di Pekanbaru', Jurnal Kesehatan Komunitas, 6(2), pp. 183-187.

Miko, A. dan Dina, P. B. (2016) 'Hubungan Pola Makan Pagi dengan Status Gizi pada Mahasiswi Poltekkes Kemenkes Aceh', Jurnal AcTion: Aceh Nutrition Journal, 1(2), pp. 83-87.

Muhayati, A. dan Ratnawati, D. (2019) 'Hubungan Antara Status Gizi dan Pola Makan dengan Kejadian Anemia Pada Remaja Putri', Jurnal Ilmiah Ilmu Keperawatan Indonesia, 9(1), pp. 563-570.

Notoatmodjo, Soekidjo (2010) Pendidikan dan Perilaku Kesehatan. Jakarta: Rineka Cipta.

Noviyanti, R. D. dan Marfuah, D. (2017) 'Hubungan Pengetahuan Gizi, Aktivitas Fisik, dan Pola Makan Terhadap Status Gizi Remaja di Kelurahan Purwosari Laweyan Surakarta', The 6th University Research Colloquium (URECOL), pp. 421-426. 
Nuryani (2019) 'Gambaran Pengetahuan, Sikap, Perilaku dan Status Gizi pada Remaja di Kabupaten Gorontalo', Jurnal Dunia Gizi, 2(2), pp.63-70.

Paramata, Y. dan Sandalayuk, M. (2019) 'Kurang Energi Kronis pada Wanita Usia Subur di Wilayah Kecamatan Limboto, Kabupaten Gorontalo', Gorontalo Journal of Public Health, 2(1), pp. 120-125.

Pujiati, Arneliawati dan Rahmalia, S. (2015) 'Hubungan antara Perilaku Makan dengan Status Gizi pada Remaja Putri', Jurnal Online Mahasiswa, 2(2), pp. 1345-1352.

Putri, M. C., Angraini, D. I. dan Handriko, R. (2019) 'Hubungan Asupan Makan dengan Kejadian Kurang Energi Kronis (KEK) pada Wanita Usia Subur (WUS) di Kecamatan Terbanggi Besar Kabupaten Lampung Tengah', Jurnal Agromedicine, 6(1), pp. 105-113.

Rahayu, S. D. dan Dieny, F. F. (2012) 'Citra Tubuh, Pendidikan Ibu, Pendapatan Keluarga, Pengetahuan Gizi, Perilaku Makan dan Asupan Zat Besi pada Siswi SMA', Media Medika Indonesiana, 46(3), pp. 184-194.

Rahayu, T. B. Dan Fitriana (2018) 'Hubungan Pola Makan dengan Status Gizi Remaja Putri di SMA Negeri 1 Bambanglipuro', Jurnal Kesehatan Samodra Ilmu, 10(2), pp. 6-10.

Ruaida, N. dan Marsaoly, M. (2017) 'Tingkat Konsumsi Energi dan Protein dengan Kejadian Kurang Energi Kronis (KEK) pada Siswa Putri di SMA Negeri 1 Kairatu', GLOBAL HEALTH SCIENCE, 2(4), pp. 361365.

Sari, P., Azizah, D. I., Gumilang, L., Judistiani, R. T. D. dan Mandiri, A. (2019) 'Asupan Zat Besi, Asam Folat, dan Vitamin C pada Remaja Putri di Daerah Jatinagor', Jurnal Kesehatan Vokasional, 4(4), pp. 169-175.

Sholicha, C. A. dan Muniroh, L. (2019) 'Hubungan Asupan Zat Besi, Protein, Vitamin C dan Pola Menstruasi dengan Kadar Hemoglobin pada Remaja Putri di SMAN 1 Manyar Gresik', Media Gizi Indonesia, 14(2), pp. 147-153.

Sitoayu, L., Pertiwi, D. A. dan Mulyani, E. Y. (2017) 'Kecukupan Zat Gizi Makro, Status Gizi, Stres, dan Siklus Menstruasi pada Remaja’, Jurnal Gizi Klinik Indonesia, 13(3), pp. 121-128.

Suryani, D., Hafiani, R. dan Junita, R. (2015) 'Analisis Pola Makan dan Anemia Gizi Besi pada Remaja Putri Kota Bengkulu', Jurnal Kesehatan Masyarakat Andalas, 10(1), pp. 11-18.

Syahfitri, E. R. (2020) 'Hubungan Pengetahuan Gizi dan Kebiasaan Makan dengan Kejadian KEK pada Remaja Putri di Model Agency Elmode Management Kota Medan', Skripsi.

Telisa, I. dan Eliza (2020) 'Asupan Zat Gizi Makro, Asupan Zat Besi, Kadar Hemoglobin dan Risiko Kurang Energi Kronis pada Remaja Putri', Jurnal AcTion: Aceh Nutrition Journal, 5(1), pp. 80-86.

Wardhani, P. I., Agustina dan Ery, M. (2020) 'Hubungan Body Image dan Pola Makan dengan Kekurangan Energi Kronis (KEK) pada Remaja Putri SMAN di Jawa Barat', JPH RECODE, 3(2), pp. 127-139.

World Health Organization (2018) Adlescent Health in the South-East Asia Region. [Online] Tersedia di: https://www.who.int/southeastasia/health-topics/adolescent-health (Diakses pada tanggal 20 Juni 2021).

Yulianasari, P., Nugraheni, S. A. dan Kartini, A. (2019) 'Pengaruh Pendidikan Gizi dengan Media Booklet Terhadap Perubahan Perilaku Remaja Terkait Pencegahan Kekurangan Energi Kronis', Jurnal Kesehatan Masyarakat (e-Journal), 7(4), pp. 420-429.

Yusinta, D. H., Pradigdo, S. F. Dan Rahfiludin, M. Z. (2019) 'Hubungan Body Image dengan Pola Konsumsi dan Status Gizi Remaja Putri di SMPN 12 Semarang’, Jurnal Kesehatan Masyarakat (e-Journal), 7(2), pp. 47-53.

Yusintha, A. N. dan Adriyanto (2018) 'Hubungan Antara Perilaku Makan dan Citra Tubuh dengan Status Gizi Remaja Putri Usia 15-18 Tahun', Amerta Nutrition, 2(2), pp. 147-154.

Zaki, I., Sari, H. P. Dan Farida (2017) 'Asupan Zat Gizi Makro dan Lingkar Lengan Atas pada Remaja Putri di Kawasan Perdesaan Kabupaten Banyumas', Prosiding Seminar Nasional dan Call for Papers Pengembangan Sumber Daya Perdesaan dan Kearifan Lokal Berkelanjutan VII, 7(1), pp. 435-441. 
Tabel 1. Perbandingan Hasil Penelitian Faktor-faktor yang Berhubungan dengan Kurang Energi Kronis (KEK)

\begin{tabular}{|c|c|c|c|c|c|}
\hline Referensi & Judul & Sampel & $\begin{array}{c}\text { Desain } \\
\text { Penelitian }\end{array}$ & Variabel & Hasil \\
\hline $\begin{array}{l}\text { (Arista et al., } \\
\text { 2017) }\end{array}$ & $\begin{array}{l}\text { Hubungan } \\
\text { Pengetahuan, } \\
\text { Sikap, Tingkat } \\
\text { Konsumsi } \\
\text { Energi, Protein, } \\
\text { dan Indeks } \\
\text { Massa } \\
\text { Tubuh/Umur } \\
\text { dengan } \\
\text { Kekurangan } \\
\text { Energi Kronik } \\
\text { pada Remaja } \\
\text { Putri }\end{array}$ & $\begin{array}{l}46 \text { remaja } \\
\text { putri kelas XI } \\
\text { SMK Islamic } \\
\text { Centre } \\
\text { Baiturrahman } \\
\text { Semarang }\end{array}$ & $\begin{array}{l}\text { Cross } \\
\text { sectional }\end{array}$ & $\begin{array}{l}\text { Variabel } \\
\text { Bebas: } \\
\text { Pengetahuan } \\
\text { tentang Gizi, } \\
\text { Sikap tentang } \\
\text { Gizi, Tingkat } \\
\text { Konsumsi } \\
\text { Energi, } \\
\text { Tingkat } \\
\text { Konsumsi } \\
\text { Protein, } \\
\text { Indeks Massa } \\
\text { Tubuh/Umur } \\
\text { Variabel } \\
\text { Terikat: } \\
\text { Kurang Energi } \\
\text { Kronik (KEK) }\end{array}$ & $\begin{array}{l}\text { - } \text { Ada hubungan } \\
\text { antara IMT/U } \\
\text { ( } \mathrm{p}=0,000) \text { dengan } \\
\text { kejadian KEK. } \\
\text { - } \text { Tidak ada hubungan } \\
\text { antara pengetahuan } \\
\text { tentang gizi } \\
\text { ( } \mathrm{p}=0,631), \text { sikap } \\
\text { tentang gizi } \\
\text { (p=0,251), tingkat } \\
\text { konsumsi energi } \\
\text { ( } \mathrm{p}=0,545), \text { dan } \\
\text { tingkat konsumsi } \\
\text { protein ( } \mathrm{p}=0,052) \\
\text { dengan kejadian } \\
\text { KEK. }\end{array}$ \\
\hline $\begin{array}{l}\text { (Ertiana dan } \\
\text { Wahyuningsih, } \\
\text { 2019) }\end{array}$ & $\begin{array}{l}\text { Asupan Makan } \\
\text { denganKejadian } \\
\text { KEK pada } \\
\text { Remaja Putri di } \\
\text { SMAN } 2 \text { Pare } \\
\text { Kabupaten } \\
\text { Kediri }\end{array}$ & $\begin{array}{l}123 \text { remaja } \\
\text { putri kelas X } \\
\text { di SMAN } 2 \\
\text { Pare } \\
\text { Kabupaten } \\
\text { Kediri }\end{array}$ & $\begin{array}{l}\text { Cross } \\
\text { sectional }\end{array}$ & $\begin{array}{l}\text { Variabel } \\
\text { Bebas: } \\
\text { Asupan } \\
\text { Makan } \\
\text { Variabel } \\
\text { Terikat: KEK }\end{array}$ & $\begin{array}{l}\text { Terdapat hubungan } \\
\text { antara jenis asupan } \\
\text { makan }(p=0,000) \text { dengan } \\
\text { kejadian KEK. }\end{array}$ \\
\hline $\begin{array}{l}\text { (Ruaida dan } \\
\text { Marsaoly, } \\
\text { 2017) }\end{array}$ & $\begin{array}{l}\text { Tingkat } \\
\text { Konsumsi } \\
\text { Energi dan } \\
\text { Protein dengan } \\
\text { Kejadian } \\
\text { Kurang Energi } \\
\text { Kronis (KEK) } \\
\text { pada Siswa } \\
\text { Putri di SMA } \\
\text { Negeri 1 } \\
\text { Kairatu } \\
\end{array}$ & $\begin{array}{l}88 \text { siswi di } \\
\text { SMA Negeri } 1 \\
\text { Kairatu }\end{array}$ & $\begin{array}{l}\text { Cross } \\
\text { sectional }\end{array}$ & $\begin{array}{l}\text { Variabel } \\
\text { Bebas: } \\
\text { Tingkat } \\
\text { Konsumsi } \\
\text { Energi dan } \\
\text { Protein } \\
\text { Variabel } \\
\text { Terikat: KEK }\end{array}$ & $\begin{array}{l}\text { Tidak ada hubungan } \\
\text { antara tingkat konsumsi } \\
\text { energi }(\mathrm{p}=0,11) \text { dan } \\
\text { protein }(\mathrm{p}=0,07) \text { dengan } \\
\text { kejadian KEK. }\end{array}$ \\
\hline $\begin{array}{l}\text { (Telisa dan } \\
\text { Eliza, 2020) }\end{array}$ & $\begin{array}{l}\text { Asupan Zat Gizi } \\
\text { Makro, Asupan } \\
\text { Zat Besi, Kadar } \\
\text { Hemoglobin dan } \\
\text { Risiko Kurang } \\
\text { Energi Kronis } \\
\text { pada Remaja } \\
\text { Putri }\end{array}$ & $\begin{array}{l}36 \text { siswi } \\
\text { berisiko KEK } \\
\text { dan } 36 \text { siswi } \\
\text { yang tidak } \\
\text { KEK kelas X } \\
\text { dan XI di } \\
\text { SMA } \\
\text { Muhammadiy } \\
\text { ah } 1 \\
\text { Palembang }\end{array}$ & $\begin{array}{l}\text { Case } \\
\text { Control }\end{array}$ & $\begin{array}{l}\text { Variabel } \\
\text { Bebas: } \\
\text { Asupan Zat } \\
\text { Gizi Makro, } \\
\text { Asupan Zat } \\
\text { Besi, Kadar } \\
\text { Hemoglobin } \\
\text { Variabel } \\
\text { Terikat: } \\
\text { Kurang Energi } \\
\text { Kronis (KEK) }\end{array}$ & $\begin{array}{l}\text { Terdapat hubungan } \\
\text { antara asupan zat } \\
\text { gizi makro (energi } \\
(\mathrm{p}=0,004) \text {, protein } \\
(\mathrm{p}=0,004) \text {, lemak } \\
(\mathrm{p}=0,031) \text { dan } \\
\text { asupan zat besi } \\
(\mathrm{p}=0,000) \text { dengan } \\
\text { kejadian KEK. } \\
\text { Tidak terdapat } \\
\text { hubungan antara } \\
\text { asupan zat gizi } \\
\text { makro (karbohidrat } \\
(\mathrm{p}=0,094) \text { ) dan kadar } \\
\text { hemoglobin } \\
(\mathrm{p}=1,000) \text { dengan } \\
\text { kejadian KEK. }\end{array}$ \\
\hline $\begin{array}{l}\text { (Wardhani et } \\
\text { al., 2020) }\end{array}$ & $\begin{array}{l}\text { Hubungan Body } \\
\text { Image dan Pola } \\
\text { Makan dengan } \\
\text { Kekurangan }\end{array}$ & $\begin{array}{l}189 \text { remaja } \\
\text { putri di SMA } \\
\text { Negeri } 6 \\
\text { Bogor }\end{array}$ & $\begin{array}{l}\text { Cross } \\
\text { sectional }\end{array}$ & $\begin{array}{l}\text { Variabel } \\
\text { Bebas: Body } \\
\text { Image dan } \\
\text { Pola Makan }\end{array}$ & $\begin{array}{l}\text { Body image (appereance } \\
\text { evaluation }(\mathrm{p}=0,000), \\
\text { appereance orientation } \\
(\mathrm{p}=0,006) \text {, area }\end{array}$ \\
\hline
\end{tabular}




\begin{tabular}{|c|c|c|c|c|c|}
\hline Referensi & Judul & Sampel & $\begin{array}{c}\text { Desain } \\
\text { Penelitian }\end{array}$ & Variabel & Hasil \\
\hline & $\begin{array}{l}\text { Energi Kronis } \\
\text { (KEK) pada } \\
\text { Remaja Putri } \\
\text { SMAN di Jawa } \\
\text { Barat }\end{array}$ & & & $\begin{array}{l}\text { Variabel } \\
\text { Terikat: } \\
\text { Kurang Energi } \\
\text { Kronis (KEK) }\end{array}$ & $\begin{array}{l}\text { satisfaction }(\mathrm{p}=0,015), \\
\text { overweight } \\
\text { preoccupation } \\
(p=0,003) \text {, dan self- } \\
\text { classified weight } \\
(\mathrm{p}=0,000)) \text { dan pola } \\
\text { makan (frekuensi makan } \\
(\mathrm{p}=0,000) \text { dan jenis } \\
\text { ragam makanan } \\
(\mathrm{p}=0,000)) \text { memiliki } \\
\text { hubungan dengan } \\
\text { kejadian KEK. }\end{array}$ \\
\hline $\begin{array}{l}\text { (Zaki et al., } \\
\text { 2017) }\end{array}$ & $\begin{array}{l}\text { Asupan Zat Gizi } \\
\text { Makro dan } \\
\text { Lingkar Lengan } \\
\text { Atas pada } \\
\text { Remaja Putri di } \\
\text { Kawasan } \\
\text { Perdesaan } \\
\text { Kabupaten } \\
\text { Banyumas }\end{array}$ & $\begin{array}{l}70 \text { remaja } \\
\text { putri dari } 3 \\
\text { SMA di } \\
\text { Kecamatan } \\
\text { Kedungbanten } \\
\text { g, Kabupaten } \\
\text { Banyumas }\end{array}$ & $\begin{array}{l}\text { Cross } \\
\text { sectional }\end{array}$ & $\begin{array}{l}\text { Variabel } \\
\text { Bebas: } \\
\text { Asupan Zat } \\
\text { Gizi Makro } \\
\text { Variabel } \\
\text { Terikat: } \\
\text { Lingkar } \\
\text { Lengan Atas } \\
\text { (LiLA) }\end{array}$ & $\begin{array}{l}\text { - } \\
\text { yerdapat hubungan bermakna } \\
\text { antara asupan zat } \\
\text { gizi makro (energi } \\
(\mathrm{p}=0,02) \text {, protein } \\
(\mathrm{p}=0,00), \text { lemak } \\
(\mathrm{p}=0,03) \text { ) dengan } \\
\text { lingkar lengan atas } \\
\text { (LiLA). } \\
\text { Tidak terdapat } \\
\text { hubungan antara } \\
\text { asupan zat gizi } \\
\text { makro (karbohidrat } \\
\text { ( } \mathrm{p}=0,06) \text { ) dengan } \\
\text { lingkar lengan atas } \\
\text { (LiLA). }\end{array}$ \\
\hline
\end{tabular}

